\title{
Halal Certification for NU Muslim in Boyolali Regency : A Study on Purchasing Decision of Alwahida Neutralizer Herbal Product, Indonesia
}

\author{
Fathan Budiman \\ LAIN Salatiga \\ fathan@iainsalatiga.ac.id \\ M. Misbahul Mujib \\ Zhongnan University of Economics and Law \\ m2m_jogja@yahoo.co.id
}

\begin{abstract}
This study used an explanatory research type with a quantitative approach. The sample used in this research was 96 respondents who were NU Muslim consumers of HPAI products in Boyolali regency by using purposive sampling. Data collection methods used in this study were the halal certification questionnaire that included dimensions of sharia, ideology, science, experience, and practice. Technique of data analysis used in this research was descriptive analysis and simple linear regression analysis. The results of the study showed that halal certification did not have a significant influence on purchasing decisions. It was proven by the value of the halal certification count of 1,715<t-table 2.2791 and the significance of $0.90>0.05$.
\end{abstract}

Keywords: halal certification, purchasing decisions, herbal product.

\begin{abstract}
Abstrak
Penelitian ini menggunakan jenis penelitian eksplanatori dengan pendekatan kuantitatif. Sampel yang digunakan dalam penelitian ini adalah 96 responden yang merupakan konsumen muslim NU produk HPAI di Kabupaten Boyolali dengan menggunakan purposive sampling. Metode pengumpulan data yang digunakan dalam penelitian ini adalah kuesioner sertifikasi halal yang meliputi dimensi syariah, ideologi, ilmu pengetahuan, pengalaman, dan praktik. Teknik analisis data yang digunakan dalam penelitian ini adalah analisis deskriptif dan analisis regresi linier sederhana. Hasil penelitian menunjukkan bahwa sertifikasi halal tidak berpengaruh signifikan terhadap keputusan pembelian. Hal tersebut dibuktikan dengan
\end{abstract}


JNUS: Journal of Nahdlatul Ulama Studies, Vol. 1, No. 2, Juli 2020: 181- 200

nilai hitung sertifikasi halal sebesar 1,715<t tabel 2,2791 dan signifikansi $0,90>0,05$.

Kata Kunci: sertifikasi halal, keputusan pembelian, produk jamu.

\section{INTRODUCTION}

Consumer behavior is manifested in decision making and individual physical activities involved in evaluating, obtaining, and using goods and services (Jusmaliani \& Nasution, 2008). The behavior of Indonesian consumers has ten unique characteristics, including short-term thinking, unplanned, like to gather, lack of technology, context-oriented, prestigious, strong in sub-culture, paying less attention to the environment, and religion (Jusmaliani and Nasution, 2009).

Taylor and McMillan (2008) state that there is a strong demand for halal products in some non-Muslim countries. Halal products are also gaining popularity among non-Muslim consumers, because Muslims treat animals well before and when they are slaughtered. As well as the perception that halal products are healthier and safer. Another important point is that halal products as business objects are not only related to getting as much profit as possible, but also with other ethical, moral, social, and religious values (Zohar \& Marshall, 2004).

A label is a part of a product that carries verbal information about the product or the seller. A label can be part of the packaging or identification that is put on by the manufacturer on the product package (Stanton in Rambe \& Afifuddin, 2012). The labeling referred to in this research is the process of writing or inclusion of halal label on packaged food. The labeling is carried out by the official agency to issue halal certification, namely the Institute for the Assessment of Food, Drugs, and Cosmetics, the Indonesian Ulema Council, or LPPOM MUI. The institute is in charge of researching, assessing and analyzing, and deciding whether food products and their derivatives, such as medicines and cosmetics, are safe for consumption both from health and Islamic perspectives. 
One of the herbal products that have been registered with LPPOM MUI and halal certification is PT Herbala Penawar Alwahida Indonesia, which is later known as HPAI. HPAI is the provision of halal and quality goods products, making HPAI one of the Halal network business companies in Indonesia. HPAI, based on the company's establishment certificate, was officially established on March 19, 2012 (https://hni.net/profile). One of the achievements that have been obtained by PT HNI-HPAI is getting a certificate of appreciation as "The Best Trusted Multi-Level Company of the Year" on 11 November 2016 (https://hni.net/profile).

In line with the increasing of public awareness regarding the use of halal products, there have been many previous studies that have discussed the public interest or intention in buying products labeled halal. Aisyah (2016) states that the intention and decision to buy halal products and personal care products will be higher if consumers are motivated by carrying out their religious obligations to consume halal products. Moreover, previously no one has released the idea of halal in cosmetics and the increased awareness of middle-class Muslims about compliance with religious rules have turned halal into a lifestyle (Yuswohadi, Madyani, Herdiansyah, \& Alim, 2014). Wahyu Widyaningrum's (2016) premium research shows that the halal label has a significant and positive influence on Wardah product purchasing decisions. The results of Suki's (2014) research explain that celebrity expertise and brand attitudes affect the purchase of halal products for Muslim consumers. Besides, the intention to purchase halal cosmetics is also influenced by product quality, halal brand imag, satisfaction, trust, and loyalty of halal brands (Ali, Xiaoling, \& Sherwani, 2018). Meanwhile, according to Rahman, Asrarhaghighi, \& Rahman (2015), the intention to purchase halal cosmetics is influenced by religiosity, knowledge, and attitude. Thus this study aims to analyze the factors influencing the purchase of halal cosmetics.

Muslims, especially NU membrs, still remember halal and haram when they are about to consume anything with the lack of products labeled halal. There are various choices of herbals, but not all are certified 
JNUS: Journal of Nahdlatul Ulama Studies, Vol. 1, No. 2, Juli 2020: 181- 200

halal. To answer this, it is necessary to conduct research on the behavior of NU Muslim consumers in Boyolali Regency towards Indonesian Alwahida Herbal Neutralizer Products.

\section{LITERATURE REVIEW}

\section{Muslim Consumer Behavior}

Consumer behavior is influenced by cultural, social, personal aspects, and psychological characteristics. Cultural factors are considered to have the greatest influence on a person's desire and behavior. Religion is a key element in life culture that influences purchasing behavior and decisions (Assadi 2003, Esso and Sally 2004, Delener 1994, Babakus et al 2004, Cornwell 2005). Religion is a system of beliefs and practices by which a group of people interprets and responds to what they feel is supernatural and sacred (Johnstone, 1975 quoted from Shafie \& Othman, 2008). In general, religion regulates what is allowed and what is forbidden to do, including consumption behavior (Shafie \& Othman, 2008).

Cloud (2000), Fam et al (2004), and also Wirthington (1988) state that religion is a belief and values in interpreting life that is expressed into a habit. Religion can influence consumer behavior and attitude in general (Delener 1994, Pettinger et al 2004), especially in purchasing decision and eating habit (Bonne et al 2007). As stated by Schiffman and Kanuk (1997), which states that the decision to buy is influenced by their religious identity (quoted from Shafie \& Othman, 2008). Therefore, as a follower of Islam, the decision to choose and buy goods will not only pay attention to the needs and costs, but the most important thing is to what extent the goods consumed will provide maximum goodness (Center for Islamic Economics Studies and Development, 2008). 


\section{Halal and Haram in Islam}

Qardhawi (2003), al-Maraghii (t.t), and Ali Ashabuni (1996) stipulate several principles regarding halal and haram in Islam: (1) basically, everything is halal, unless there is a prohibition; (2) sanctification and prohibition are only the authority of Allah; (3) To forbid what is halal and what is haram is including polytheism; (4) something is forbidden because it is bad and dangerous; (5) something halal makes us no longer need anything that is haram; (6) something that leads to what is haram is haram; (7) dealing with what is haram is haram; (8) good intentions do not justify what is haram; (9) avoid the unclear (syubhat) so as not to fall into the haram; (10) what is haram is haram for all; (11) emergency situations make what is haram permissible.

\section{Halal Certification}

According to Lada, et al. (2009) halal certification is a safety for a Muslim consumer to choose products that are good for him and in accordance with Islamic law. Products that have halal certification are products in which the process meets standards in safety and cleanliness. Halal certification guarantees the safety of a product so that it can be consumed by Muslims (Yasmirah Mandasari, 2019).

According to Law Number 33 of 2014 concerning Halal Product Guarantee paragraph 10, a halal certificate is an acknowledgment of the halal of a product issued by BPJPH (Institute of Halal Product Guarantee Management) based on a written fatwa issued by MUI (https: //www.halal MUI .org). The purpose of halal certification is to obtain legal formal recognition that the product has met halal requirement. This halal certification is in the form of a certificate issued by the Central or 
JNUS: Journal of Nahdlatul Ulama Studies, Vol. 1, No. 2, Juli 2020: 181- 200

Provincial MUI regarding the halal food, beverage, medicinal and cosmetic product produced by the company after being examined and declared halal by LPPOM MUI (Farhan, 2018).

In Indonesia halal certification is issued by the Indonesian Ulema Council (MUI) form 16 to 17 October 2019, the issuance of halal certification is the authority of the Halal Product Guarantee Agency (BPJPH) (https: / / www.cnnindonesia.com/). Products that have halal certification are those have been tested for halal and can be consumed by Muslims.

Since the enactment of Law No. 33 of 2014 concerning Halal Product Guarantee which contains mandatory provisions for halal certification, including for used goods, a number of producers have obtained halal certification from MUI. In recent years, the demand for halal certification at MUI has increased and varied. Halal certification for used goods products continue to grow every year (https://www.halalmui.org).

\section{RESEARCH METHODS}

Data collection techniques used in this study were: 1) The questionnaire, it was a data collection technique carried out by giving a set of questions or written statements to the respondent to answer. 2) library research (library research), this research was conducted by holding activities to collect materials through reading books, other literature related to the topic of this study.

The population in this study was all HPAI herbal users in Boyolali Regency. The population in this study cannot be known exactly. Sampling technique used in this study is purposive random sampling. The 
researcher found 96 NU Muslims in Boyolali Regency as users of HPAI herbal products (Sugiyono, 2016).

Since this study examines the influence of halal certification on purchasing decisions for HPAI herbal products, analysis technique used in this study is quantitative analysis. Grouping data based on variables and types of respondents, tabulating data based on variables from all respondents, presenting data for each variable studied, performing calculations to answer the problem statements, and performing calculations to test the hypotheses that have been proposed (Imam Ghozali, 2006)

The classical assumption test was carried out as a first step before analyzing data using regression to obtain an unbiased and efficient analysis model from the regression equation. Simple linear regression analysis was carried out after previously having tested the validity, reliability, normality, and heteroscedasticity (Meilia Nur Indah S, 2010).

After the results of simple regression analysis are obtained, the next step is to test the results of the analysis with statistical tests (Hasan, 2006). This statistical test is intended to determine whether or not the relationship between variables is significant through the regression coefficient. The statistical test used in simple linear regression in this study is t-test (Damodar Gujarti, 2010)

\section{RESULTS OF DATA ANALYSIS}

Male espondents were $37.5 \%$ or 36 NU Muslim respondents, and female respondents were $62.5 \%$ or 60 NU Muslim respondents. Respondents aged 15-25 years were 46 or $47.9 \%$, those aged 26-35 years were 35 respondents or $36.5 \%$, and respondents aged $>35$ years were 15 or $15.6 \%$. 
JNUS: Journal of Nahdlatul Ulama Studies, Vol. 1, No. 2, Juli 2020: 181- 200

Respondents as private employees were 21 people or $21.9 \%$, students were 37 people or $38.5 \%$, civil servants were 4 people or $4.2 \%$, entrepreneurs were 23 people or $24 \%$, and others 11 people or $11.5 \%$. Respondents who used HPAI products $<1$ year were 17 people or $17.7 \%$, 1-3 years were 47 people or 49\%, 4-5 years were 13 people or $13.5 \%$, and those who used $>5$ years were 19 people or $19.8 \%$.

Table 1

\section{Validity Test Result}

\begin{tabular}{|l|l|l|l|l|}
\hline Variable & Questions & $\mathbf{R}_{\text {count }}$ & $\mathbf{r}_{\text {table }}$ & Note \\
\hline \multirow{3}{*}{$\begin{array}{l}\text { Halal } \\
\text { Certification } \\
(\mathrm{X} 1)\end{array}$} & Question 1 & $0,746^{* *}$ & & V alid \\
\cline { 2 - 3 } & Question 2 & $0,841^{* *}$ & & V alid \\
\cline { 3 - 3 } & & & \\
\cline { 2 - 3 } & Question 3 & $0,825^{* *}$ & \multirow{4}{*}{0,1689} & V alid \\
\cline { 2 - 3 } & Question 4 & $0,902^{* *}$ & & V alid \\
\cline { 2 - 3 } & Question 5 & $0.800^{* *}$ & & V alid \\
\hline
\end{tabular}

Based on the table above, it is known that all questions used in the questionnaire are valid. All questions in the variable have $\mathrm{r}$ count more than $\mathrm{r}$ table, namely 0.1689 with a significance level of $5 \%$.

Table 2

\section{Reliability Test Result}

\begin{tabular}{|l|l|l|}
\hline Variable & Cronbach Alpha & Note \\
\hline $\begin{array}{l}\text { Halal Certification } \\
\text { (X1) }\end{array}$ & 0,880 & Reliabel \\
\hline
\end{tabular}

The results of the variable construct reliability testing used in this study showed that the Cronbach Alpha value was greater than 0.60. This means that all instruments in this study are reliable so that all questions can be trusted and used for further research. 
Table 3

\section{Heteroscedasticity Test of Equation 1}

Coefficients $^{\mathrm{a}}$

\begin{tabular}{|c|c|c|c|c|c|c|}
\hline \multirow{2}{*}{\multicolumn{2}{|c|}{ Model }} & \multicolumn{2}{|c|}{$\begin{array}{c}\text { Unstandardized } \\
\text { Coefficients }\end{array}$} & $\begin{array}{l}\text { Standardized } \\
\text { Coefficients }\end{array}$ & \multirow[t]{2}{*}{$\mathrm{T}$} & \multirow[t]{2}{*}{ Sig. } \\
\hline & & $\mathrm{B}$ & Std. Error & Beta & & \\
\hline \multirow{2}{*}{1} & (Constant) & 9.529 & 1.940 & & 4.913 & .000 \\
\hline & Halal Certification & -.008 & .056 & -.020 & -.149 & .882 \\
\hline
\end{tabular}

Table 4

Heteroscedasticity Test of Equation 2

Coefficients $^{a}$

\begin{tabular}{|c|c|c|c|c|c|c|}
\hline \multirow{2}{*}{\multicolumn{2}{|c|}{ Model }} & \multicolumn{2}{|c|}{$\begin{array}{c}\text { Unstandardized } \\
\text { Coefficients }\end{array}$} & $\begin{array}{l}\text { Standardized } \\
\text { Coefficients }\end{array}$ & \multirow[b]{2}{*}{$\mathrm{T}$} & \multirow[b]{2}{*}{ Sig. } \\
\hline & & B & Std. Error & Beta & & \\
\hline \multirow[t]{2}{*}{1} & (Constant) & 4.998 & 1.068 & & 4.679 & .000 \\
\hline & Sertifikasi Halal & .058 & .031 & .252 & 1.873 & .064 \\
\hline
\end{tabular}

In the heteroscedasticity test results equation 1 shows a significant value for the Halal Certification variable of 0.882, and equation 2 shows a significant value for the Halal Certification variable of 0.064. All significant values $>0.05$, this means homoscedasticity. Based on the test results, it can be concluded that there are no symptoms of heteroscedasticity.

Table 5

Equation Normality Test One-Sample Kolmogorov-Smirnov Test

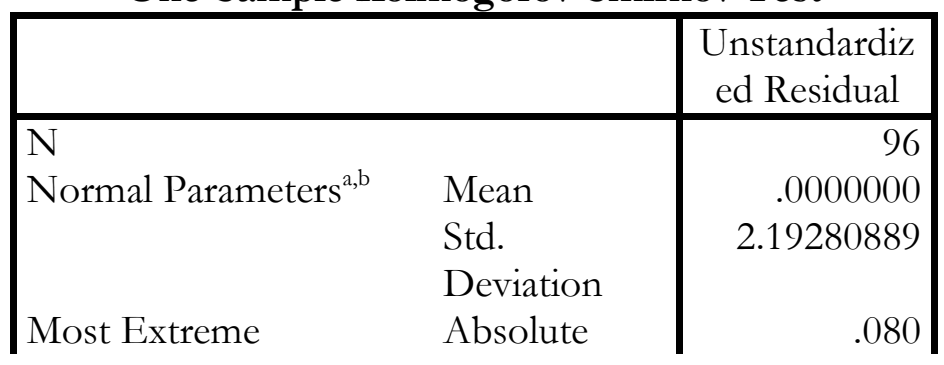


JNUS: Journal of Nahdlatul Ulama Studies, Vol. 1, No. 2, Juli 2020: 181- 200

\begin{tabular}{|lr|r|} 
Differences & Positive & .041 \\
\multicolumn{2}{|c|}{ Negative } & -.080 \\
Kolmogorov-Smirnov Z & .786 \\
Asymp. Sig. (2-tailed) & .568 \\
\hline
\end{tabular}

a. Test distribution is Normal.

b. Calculated from data.

The results of the One-Sample Kolmogrorov-Smirnov Test on the equation show that the significance is 0.568 . So it can be concluded that the data is normally distributed.

Table 6

\section{Autocorrelation Test Result}

Model Summary ${ }^{\mathrm{b}}$

\begin{tabular}{lr|r|r|r|r} 
Model & $\mathrm{R}$ & R Square & $\begin{array}{c}\text { Adjusted R } \\
\text { Square }\end{array}$ & $\begin{array}{c}\text { Std. Error of } \\
\text { the Estimate }\end{array}$ & \multicolumn{1}{c}{$\begin{array}{c}\text { Durbin- } \\
\text { Watson }\end{array}$} \\
\hline 1 & $.870^{\mathrm{a}}$ & .756 & .745 & 2.24048 & 1.806 \\
\hline
\end{tabular}

a. Predictors: (Constant), Sertifikasi Halal

b. Dependent Variable: Keputusan Pembelian

In the table above, the Durbin Watson value is 1.806 . This means that it is greater than $\mathrm{du}=1.7553$ obtained through the Durbin Watson table with a significance of $5 \%$ and $4-\mathrm{du}=4-1,7553=2.2447$. So that $\mathrm{du}<\mathrm{d}<4-\mathrm{du}$ $=1.7553<1.806<2.2447$, so it can be concluded that there is no autocorrelation in the equation.

\section{Table 7}

\section{Coefficient Test}

Coefficients tes result ${ }^{\mathrm{a}}$ Equation 2

Unstandardized Standardized Coefficients Coefficients

\begin{tabular}{llr|r|r|r|r} 
& & \multicolumn{2}{c}{ Coefficients } & Coefficients & & \\
& \multicolumn{1}{c}{ B } & Std. Error & Beta & \multicolumn{1}{c}{ t } & \multicolumn{1}{c}{ Sig. } \\
\hline 1 & (Constant) & 3.057 & 1.941 & & 1.575 & .119 \\
\cline { 2 - 7 } & Halal certification & .097 & .057 & .126 & 1.715 & .090 \\
\hline
\end{tabular}

a. Dependent Variable: Purchasing Decission

From the analysis of the coefficient values of each variable above, it can be seen that the simple linear regression equation is formed. The simple 
linear regression equation that is formed is: $\mathrm{Y}=3.057+0.097 \mathrm{X}+\mathrm{e}$. Then the t-test is carried out to test the significance of the effect of halal certification on purchasing decisions partially.

Table 8

\section{T-test Result}

\section{Coefficients $^{\mathrm{a}}$}

Unstandardized Standardized

Coefficients Coefficients

\begin{tabular}{lr|r|r|r|r} 
Model & \multicolumn{1}{c}{ B } & Std. Error & Beta & T & \multicolumn{1}{c}{ Sig. } \\
\hline 1 (Constant) & 3.057 & 1.941 & & 1.575 & .119 \\
\hline Halal Certification & .097 & .057 & .126 & 1.715 & .090 \\
\hline
\end{tabular}

a. Dependent Variable: Purchasing Vriable

From the table above, it shows that the value of halal certification t-count is $1.715<\mathrm{t}$-table 2.2791 and a significance of $0.90>0.05$, it can be concluded that halal certification has a positive and insignificant influence on purchasing decisions.

\section{RESEARCH FINDINGS AND DISCUSSION}

Researcher asked questions through questionnaires to $96 \mathrm{NU}$ Muslim respondents in Boyolali Regency regarding aspects of halal certification. This question contains five dimensions; those are (Glock and Stark in Reitsma, 2006): ritual (syari'ah), ideological (aqidah), intellectual (knowledge), experience or appreciation (experient), and consequential dimensions (practice). The decision to buy halal products referred to in this research is the best conclusion for individual consumer to make purchases based on the decision-making process that they have been through, including individual consumer actions in buying products related to the halal label (Kotler, 2009).

The Likert scale is used as a variable measurement tool, using an interval scale in the form of a checklist (Cohen, Manio, and Morrison, 
JNUS: Journal of Nahdlatul Ulama Studies, Vol. 1, No. 2, Juli 2020: 181- 200

2011). Each respondent was asked to indicate his or her approval or disagreement on each statement on a scale between 1 (strongly disagree) to 10 (Strongly agree).

The ritual dimension (sharia) does not have a significant influence on purchasing decisions for the HPAI. The results of the respondents' answers to the statements in the ritual dimension have a fairly high average value, namely 8.75 . This means that respondents are obedient in carrying out religious orders, by choosing halal goods to fulfill their daily needs. However, this dimension does not have a significant influence on consumer's purchasing decisions for halal products. This is because respondents think that choosing products that are labeled halal is indeed an obligation, regardless of their decision to buy HPAI halal products. Ritual dimensions appear in concrete matters and are directly related to the implementation of religious orders, while the decision to purchase halal products is more directed at muamalah activities that do not involve religious rituals in the implementation.

The ideological dimension does not have a significant influence on the decision to purchase HPAI halal products. The results of respondents' answers to statements in the ideological dimension have a very high average value of 8.78 . This means that respondents have the belief that it is proper to label a product as halal and that halal certification on HPAI products is officially issued by MUI. However, this dimension does not have a significant influence on consumer's purchasing decisions for HPAI halal products. This is because respondents think that the legality of MUI is no longer questionable, in purchasing decisions, it is perceived as a muamalah activity that is not directly related to the ideological aspect and not a belief (ideology) that must be maintained and fulfilled. 
The intellectual and experience dimensions do not have a significant influence on the purchasing decision of HPAI halal products, even though the average value of respondents' statements for these two dimensions is quite high, 8.65 and 8.57. Respondents' statements for these two dimensions have a moderate average value among other dimensions. Respondents' answers indicated that they accept Islamic truth about the prohibition of using haram products. The inculcation of Islamic teachings was obtained before, not from strong logical arguments and thoughts. Respondents' answers to statements about efforts to increase understanding of religion and increase religious knowledge through scientific activities or reading religious books were also relatively low. This shows that because of their reluctance to add insight and religious knowledge, most respondents also do not understand the essence of the importance of the halal product. In general, as long as a product does not contain pork, it is considered halal. Whereas in fact, many food products use additives such as emulsifiers, preservatives, and so on, which are derivative product or extract from one part of the pig's body. This is so much unknown to the Islamic community itself, due to a lack of insight into religious sciences.

The practice dimension (consequence) also does not have a significant influence on purchasing decisions for HPAI halal products. The results of respondents' 'nswers to respondents' statements in the practice dimension have a fairly high average value and the lowest average value compared to other dimensions, namely 8.55. This means that consumers' decisions to buy halal products are based entirely on their consequences as Muslims. Respondents do not have the commitment to apply Islamic teachings entirely in their daily lives, by always consuming 
JNUS: Journal of Nahdlatul Ulama Studies, Vol. 1, No. 2, Juli 2020: 181- 200

the halal and leaving the haram. One of the interesting things obtained in this research is that although respondents stated that it is important to include halal labels in product packaging and they try to buy products with halal packaging if it turns out that the product that has been purchased does not contain a halal label, it is still consumed and not thrown away or given to others.

\section{CONCLUSION}

Based on the t-test conducted in this study, it is known that the halal certification aspects of HPAI products do not have a significant influence on purchasing decisions for HPAI halal products. This happens because it is influenced by the need to consume products labeled halal is not an urgent need, the important thing is that these products are clearly not made from pork and materials prohibited by religion. Appreciation and continuity of the meaning of the dimensions of ritual, ideology, intellectual, experience, and practice in the aspects of halal certification are still not comprehensive, deep, and optimal.

\section{REFERENCES}

Aisyah, M. (2016). Consumer Demand on Halal Cosmetics and Personal Care Products in Indonesia. Al-Iqtishad: Journal of Islamic Economics, $9(95)$

125-142. DOI: http://dx.doi.org/10.20473/jebis.v4i2.10501. Diakses pada tanggal 2 Mei 2020

Ali, A., Xiaoling, G., \& Sherwani, M. (2018). Antecedents of Consumers' Halal Brand Purchase Intention: an Integrated Approach. Management Decision, Vol. 56 Issue: 4, 715-735. DOI: https://doi.org/10.1108/MD-11-2016-0785. Diakses pada tanggal 3 Mei 2020 
Al-Maraghi, Ahmad Mustofa, (t.t). Tafsir al-Maraghi, Dar al-Hayak alTurats al-'Arabi. Beirut.

Al-Shabuni, Muhamaad Ali. (1996). Rawai'u al-Bayan Tafsir Ayat al-Abkam, Dar al-Fikri. Beirut.

Assadi, Djamchid. (2003). Do Religions Influence Customer Behavior? Confronting Religious Rules And Marketing Concepts. Cahiers Du Ceren Vol. 5. Hal. 2-13. https://www.researchgate.net/profile/Djamchid Assadi/public ation/242109368 Do Religions Influence Customer Behavior Confronting religious rules and marketing concepts/links $/ 5$ 49db7ab0cf2fedbc311989d.pdf. Diakses pada tanggal 2 Mei 2020

Awan, H. M., Siddiquei, A. N., \& Haider, Z. (2015). Factors Affecting Halal Purchase Intention - Evidence From Pakistan'S Halal Food Sector . International Journal of Commerce and Management, 38(1), 8-20 DOI: https://doi.org/10.1108/MRR01-2014-0022. Diakses pada tanggal 2 Mei 2020

Babakus, Emin, T. Bettina Cornwell, Vince Mitchell, Bodo Schlegelmilch. (2004). Reactions To Unethical Consumer Behavior Across Six Countries. Journal of Consumer Marketing Vol. 21 Issue: 4. Hal. 254263. DOI: https://doi.org/10.1108/07363760410542165. Diakses pada tanggal 2 Mei 2020

Bonne, Karijn et Wim Verbeke (2007). Muslim Consumer's Motivations Towards Meat Consumption In Belgium: Qualitative Exploratory Insights From Means-End Chain Analysis. Anthropology of food (Online). DOI: https://doi.org/10.4000/aof.90. Diakses pada tanggal 2 Mei 2020

Bonne, Karijn et Wim Verbeke (2007). Muslim Consumer's Motivations Towards Meat Consumption In Belgium: Qualitative Exploratory Insights From Means-End Chain Analysis. Anthropology of food (Online) DOI: https://doi.org/10.4000/aof.90. Diakses pada tanggal 3 Mei 2020.

Cohen, L., Manion, L., \& Morrison, K. (2011). Research Methods in Education. Routlege: New York. https://www.researchgate.net/profile/Keith Morrison3/publica tion/44824604 Research Methods in Education/links/5406e3 900cf2bba34c1e6fe8/Research-Methods-in-Education.pdf.

Diakses pada tanggal 2 Mei 2020

Cornwell, Bettina, Charles Chi Cui, Vince Mitchell, Bodo Schlegelmilch, Anis Dzulkiflee, Joseph Chan (2005). A Cross-Cultural Study Of The Role Of Religion In Consumers' Ethical Positions. 
JNUS: Journal of Nahdlatul Ulama Studies, Vol. 1, No. 2, Juli 2020: 181- 200

International Marketing Review. Vol. 22 Issue: 5 Hal. 531-546. DOI: https://doi.org/10.1108/02651330510624372. Diakses pada tanggal 2 Mei 2020

Delener, Nejdet (1994). Religious Contrasts in Consumer Decision Behaviour Patterns: Their Dimensions and Marketing Implications. European Journal of Marketing.Vol. 28 Issue: $5 \mathrm{Hal}$. 36-53. DOI: https://doi.org/10.1108/03090569410062023. Diakses pada tanggal 2 Mei 2020

Delener, Nejdet (1994). Religious Contrasts in Consumer Decision Behaviour Patterns:Their Dimensions and Marketing Implications. European Journal of Marketing. Vol. 28 Issue: 5. Hal. 36-53. DOI: https://doi.org/10.1108/03090569410062023. Diakses pada tanggal 2 Mei 2020

Delener, Nejdet. (1994). Religious Contrasts in Consumer Decision Behaviour Patterns: Their Dimensions and Marketing Implications. European Journal of Marketing. Vol. 28 Issue: 5 Hal. 36-53. DOI: https://doi.org/10.1108/03090569410062023. Diakses pada tanggal 3 Mei 2020.

Essoo, Nittin and Dibb, Sally. (2004). Religious Influences On Shopping Behaviour: An Exploratory Study. Journal of Marketing Management, 20 (7-8). Hal. 683-712. DOI: https://doi.org/10.1362/0267257041838728. Diakses pada tanggal 2 Mei 2020

Farhan, Ahmad. (2018). Pelaksanaan Sertifikasi Halal Lppom Mui Terhadap Produk Usaha Mikro, Kecil Dan Menengah (UMKM) (Studi LPPOM MUI Provinsi Bengkulu), Manhaj: Jurnal Penelitian dan Pengabdian Masyarakat Vo. 3(1).

DOI: http://dx.doi.org/10.29300/mjppm.v3i1.2340.g1949._Diakses pada tanggal 2 Mei 2020

Ghozali, Imam. (2006). Aplikasi Analisis Multivariate Dengan Program SPSS. Semarang: Badan Penerbit Universitas Diponegoro.

Gujarati, Damodar. (2010). Basic Econometrics, New York: Mc Graw Hill Inc.

http://repository.fue.edu.eg/xmlui/bitstream/handle/12345678 9/2665/4979.pdf?sequence $=1$ \&isAllowed $=$ y. Diakses pada tanggal 2 Mei 2020.

Hasan, Iqbal. (2006). Analisis Data Penelitian Dengan Statistik, cet. ke-2, Jakarta: Bumi Aksara

https://www.cnnindonesia.com/nasional/20191017124156-20440322/sertifikasi-halal-di-tangan-kemenag-mui-masih-berperanbesar. Diakses pada tanggal 2 Mei 2020. 
Halal Certification for NU Muslim ... (Fathan Budiman \& M. Misbahul Mujib)

https://www.halalmui.org/mui14/. Diakses pada tanggal 1 Mei 2020 https://www.researchgate.net/profile/Siti Rahayu Hussin/publication/2 76160302 Relationship between Product Factors Advertising and Purchase Intention of Halal Cosmetic/links/55ecee7608a e3e121847f72e.pdf. Diakses pada tanggal 3 Mei 2020

https://www.tribunnews.com/kesehatan/2018/11/23/daftar-115-obatherbalal-dan-suplemen-yang-ditarik-bpom-karena-mengandungbahan-kimia. Diakses pada tanggal 2 Mei 2020.

Hussin, S. R., Hashim, H., Yusof, R. N., \& Alias, N. N. (2013). Relationship between Product Factors, Advertising, and Purchase Intention of Halal Cosmetic. Pertanika Journals Social Scientis and Humanities 85-100. https://www.researchgate.net/profile/Siti Rahayu Hussin/publ ication/276160302 Relationship between Product Factors Ad vertising and Purchase Intention of Halal Cosmetic/links/55 ecee7608ae3e121847f72e.pdf. Diakses pada tanggal 2 Mei 2020

Indah, Meilia Nur. (2010). Statistik Deskriptif Dan Induktif, cet. ke-1, Yogyakarta: Graha Ilmu

Jusmaliani \& Hanny Nasution. (2008). Religiosity Aspect in Consumer Behaviour: Determinants of Halal Meat Consumption Centre for Economic and Development Studies, Indonesian Institute of Sciences Department of Marketing, Monash University Jurnal NCMR DOI: https://doi.org/10.21002/amj.v1i1.1977. Diakses pada tanggal 3 Mei 2020

(2009). Religiosity Aspect in Consumer Behaviour: Determinants of Halal Meat Consumption, Asean Marketing Journal. June 2009, Vol I-No.1. DOI: https://doi.org/10.21002/amj.v1i1.1977. Diakses pada tanggal 3 Mei 2020

Kotler, Philip, dan Kevin Lane Keller. (2009). Manajemen Pemasaran. Edisi Ketiga Belas Jilid 1. Jakarta: Erlangga

Lada, S., Tanakinjal, H. G., dan Amin, H. (2009) . Predicting Intention To Choose Halal Products Using Theory Of Reasoned Action. International Journal Islamic and Middle Eastern Finance and Management 2 (1). DOI: https://doi.org/10.1108/17538390910946276. Diakses pada tanggal 2 Mei 2020

Mandasari, Yasmirah. (2019). Sanksi Pidana Terhadap Kandungan Non Halal Terhadap Produk Makanan Bersertifikat Halal Yang Dilakukan Korporasi. Soumatera Law Review 
JNUS: Journal of Nahdlatul Ulama Studies, Vol. 1, No. 2, Juli 2020: 181- 200

(http://ejournal.kopertis10.or.id/index.php/soumlaw) Vol. 2 (2). DOI: http://doi.org/10.22216/soumlaw.v2i2.4339. Diakses pada tanggal 2 Mei 2020

Pettinger, C., Holdsworth, M., Gerber, M., (2004). Psycho-Social Influences On Food Choice In Southern France And Central England. Appetite, Vol. 42 (3), 307-316. DOI: https://doi.org/10.1016/j.appet.2004.01.004. Diakses pada tanggal 2 Mei 2020

Pusat Pengkajian dan Pengembangan Ekonomi Islam. (2008). Ekonomi Islam. PT. Raja Grafindo Persada: Jakarta

Qardhawi, Yusuf. Al-halal wa al-haram fi al-Islami. (1994). Al-Maktab alIslami.

Rahman, A. A., Asrarhaghighi, E., \& Rahman, S. A. (2015). Consumers and Halal Cosmetic Products: Knowledge, Religiosity, Attitude and Intention. Journal of Islamic Marketing, Vol. 6, 148-163 DOI: https://doi.org/10.1108/JIMA-09-2013-0068. Diakses pada tanggal 2 Mei 2020

Rambe, Y. M., \& Afifuddin, S. (2012). Pengaruh Pencantuman Label Halal pada Kemasan Mie Instan terhadap Minat Pembelian Masyarakat Muslim (Studi Kasus pada Mahasiswa Universitas AlWashliyah, Medan).. Jurnal ekonomi dan Keuangan, 1(1). DOI: http://dx.doi.org/10.15548/jebi.v3i2.175. Diakses pada tanggal 3 Mei 2020

Reitsma, Jan, dkk. (2006). Dimension of Individual Religiosity and Charity: Cross National Effect Differences in European Countries. On Review of Religious Research. Vo. 47 (4). PP: 347-362. https://www.jstor.org/stable/20058103. Diakses pada tanggal 2 Mei 2020

Shafie S, Othman N Md, (2006). Halal Certification: An International Marketing Issues And Challenges. http://www.ctwcongress.de/ifsam/download/track 13/pap00226. pdf. Diakses pada 2 Mei 2020.

Sugiyono. (2016). Metode Penelitian Pendidikan Pendekatan Kuantitatif Kualitatif dan R \& D. Bandung: Alfabeta.

Suki, N. M. (2014). Does Celebrity Credibility Influence Muslim and NonMuslim Consumers' Attitudes Toward Brands and Purchase Intention? Journal of Islamic Marketing, Vol. 5 Issue: 2, 227-240. DOI: https://doi.org/10.1108/JIMA-02-2017-0014. Diakses pada tanggal 3 Mei 2020

Taylor, Eric dan Ann McMillan. (2013). Air Quality Management: Canadian Perspectives on a Global Issue. Springer Dordrecht 
Halal Certification for NU Muslim ... (Fathan Budiman \& M. Misbahul Mujib)

Heidelberg New York London.

DOI:

https://doi.org/10.1007/978-94-007-7557-2. Diakses pada tanggal 2 Mei 2020.

Wahyu Widyaningrum, Premi. (2016). Pengaruh Label Halal Dan Celebrity Endorser Terhadap Keputusan Pembelian (Survei Pada Konsumen Wardah Di Ponorogo). Jurnal Ekonomi Syariah Indonesia. $\quad$ Vol. 6 (2). Hal. 83-98. DOI: http://dx.doi.org/10.21927/jesi.2016.6(2).\%25p. Diakses pada tanggal 3 Mei 2020

Yuswohadi, Madyani, D., Herdiansyah, I. A., \& Alim, I. (2014). Marketing to the Middle Class Muslim. Jakarta: PT. Gramedia Pustaka Utama 